\title{
Identification and Agronomic Performance of Species of the Genus Amaranthus Grown in Burkina Faso
}

\author{
Ouedraogo Jacques ${ }^{1, ~ *, ~ K i e b r e ~ M a r i a m ~}{ }^{1}$, Kabore Boukare ${ }^{3}$, Sawadogo Boureima ${ }^{2}$, Kiebre Zakaria ${ }^{1}$, \\ Bationo Kando Pauline ${ }^{1}$ \\ ${ }^{1}$ Genetics and Plant Amélioration Unit, Joseph KI ZERBO University, Ouagadougou, Burkina Faso \\ ${ }^{2}$ Genetics and Plant Amélioration Unit, University of Fada-N'Gourma, Fada-N'Gourma, Burkina Faso \\ ${ }^{3}$ Institute of Environment and Agricultural Research, National Center of Scientific and Technological Research, Bobo Dioulasso, Burkina \\ Faso
}

\author{
Email address: \\ ouedjak@gmail.com (O. Jacques) \\ ${ }^{*}$ Corresponding author
}

\section{To cite this article:}

Ouedraogo Jacques, Sawadogo Boureima, Kabore Boukare, Kiebre Mariam, Kiebre Zakaria, Bationo/Kando Pauline. Identification and Agronomic Performance of Species of the Genus Amaranthus Grown in Burkina Faso. International Journal of Applied Agricultural Sciences. Vol. 7, No. 2, 2021, pp. 102-109. doi: 10.11648/j.ijaas.20210702.15

Received: March 22, 2021; Accepted: April 12, 2021; Published: April 30, 2021

\begin{abstract}
The present study was carried out on eighty (80) accessions from Burkina Faso. It has a double objective: to identify the different species of amaranths cultivated and to estimate their agronomic performances. To this end, twenty-four (24) descriptors were used to characterize the collection, according to a Fisher block design with three replications. The survey was conducted at the IDR experimental site in Gampèla. The study revealed a great phenotypic diversity characterized by the existence of qualitative discriminating characters of which the color of the stem and the leaves, the shape and the size of the leaves as well as the color of the inflorescence. These observations allowed us to identify seven morphotypes belonging to three species: Amaranthus cruentus, Amaranthus hypochondriacus and Amaranthus dubius. The analysis of variance showed several discriminating quantitative characters including height, stem diameter, number of branches and number of days to flowering. The green-leaved Amaranthus cruentus species showed the highest yields of leaf biomass $(283.57 \mathrm{~g})$ with a long flowering cycle (72.5 days) and a high number of branching (45.6). Oval-leaved accessions with broad, long blades and early flowering were identified belonging to the species Amaranthus dubius. The light green morphotype of Amaranthus hypochondriacus species and accessions of Amaranthus dubius species yielded low foliar biomass.
\end{abstract}

Keywords: Amaranthus ssp, Identification, Species, Burkina Faso

\section{Introduction}

Amaranths are traditional leafy vegetables popular in most African countries [1, 2]. They are characterized by a high diversity and capacity to adapt to different agro-climatic conditions [3-5]. Being C4 type plants like maize and sugarcane, amaranths have a carbon sequestration capacity, which allows them to have a high production of dry matter and protein per unit area [6]. In Burkina Faso, commonly called "Bolombourou" in the local Mooré language, amaranths occupy a prominent place in market gardening. They form with sorrel (Hibiscus sabdariffa), the vegetable cornet (Corchorus olitorius), the main leafy vegetables most consumed in urban and peri-urban areas. In the city of
Ouagadougou (capital of Burkina Faso), they occupy the first place [7]. In 2018, the national production of amaranth was estimated at 1357 tons on an area of 246 hectares. In the city of Ouagadougou alone, the production was 1140 tons on an area of 191 hectares [8]. The leaves and tender twigs of amaranth are used in the preparation of various local dishes. Their sale provides important incomes to producers, contributing to the fight against poverty, especially that of women [9]. Due to their high protein, vitamin $\mathrm{C}$, calcium, iron and zinc content, they are a good dietary supplement $[10,11]$. Thus, with a high child malnutrition rate of $20.1 \%$ in Burkina Faso [12], the valorization and improvement of this genetic resource could contribute to the fight against nutritionally deficiency childhood diseases.

However, the taxonomic status and interspecific 
relationship of the genus is poorly understood due to the wide phenotypic variation. This variation is due, among others things, to the sporadic hybridization between species [11, 13]. According to Vojtech Lanta and Mayuri J, the relatively easy hybridization with a degree of allogamy of $5 \%$ to $31 \%$ leads to the appearance of new phenotypic characters [14, $15]$.

The knowledge of this genetic diversity and the variations in the morphological traits in populations is essential. It allows the elaboration of selection programs and conservation strategies for these resources. In Burkina Faso, the genetic diversity of the amaranths is still poorly known. This study aims to identify the different species of cultivated lamb's quarters using morphological markers.

\section{Material and Methods}

\subsection{Plant Material}

The plant material of the study consists of eighty (80) accessions of amaranth collected in 2016 from market gardeners in the three agro-climatic zones of Burkina Faso (figure 1). Thus, six (06) accessions were collected in the Sudanian zone, forty-six (46) in the Sudano-Sahelian zone and twenty-eight (28) in the Sahelian zone.

\subsection{Experimental Site Device and Cultivation Practice}

The trial was performed in the experimental station of the Institute of Rural Development (IDR) of Gampèla on a sandy-clay soil. This site is located at $20 \mathrm{Km}$ from Ouagadougou, on the Ouaga-Niger axis at $12^{\circ} 15^{\prime}$ North latitude and $1^{\circ} 12^{\prime}$ West longitude. The climate is of the Sudano-Sahelian type with a rainfall that undergoes great inter-monthly variations during the year (Figure 2). The average precipitation for the 2018-2019 crop year from June to October is $706,7 \mathrm{~mm}^{3}$. The annual maximum and minimum temperature ranges from $30,05^{\circ} \mathrm{C}$ in June and from $27,92^{\circ} \mathrm{C}$ in August, respectively.

The experimental device set-up performed was a Fischer block with three repetitions of $2 \mathrm{~m}$ apart in each block. Each accession is represented by a line of $5.25 \mathrm{~cm}$ with 07 poquets. The line spacing and the inter-poquets were 0.75 $\mathrm{cm}$.

Seeds were placed in nurseries in pots and transplanted 30 days later on the experimental plot. Before transplanting, the soil was deeply tilled and levelled, and had received some organic bottom manure at the rate of 20 tons/ha. Two weeks after transplanting, NPK fertilizer (15-15-15) was applied (100 kg/ha).

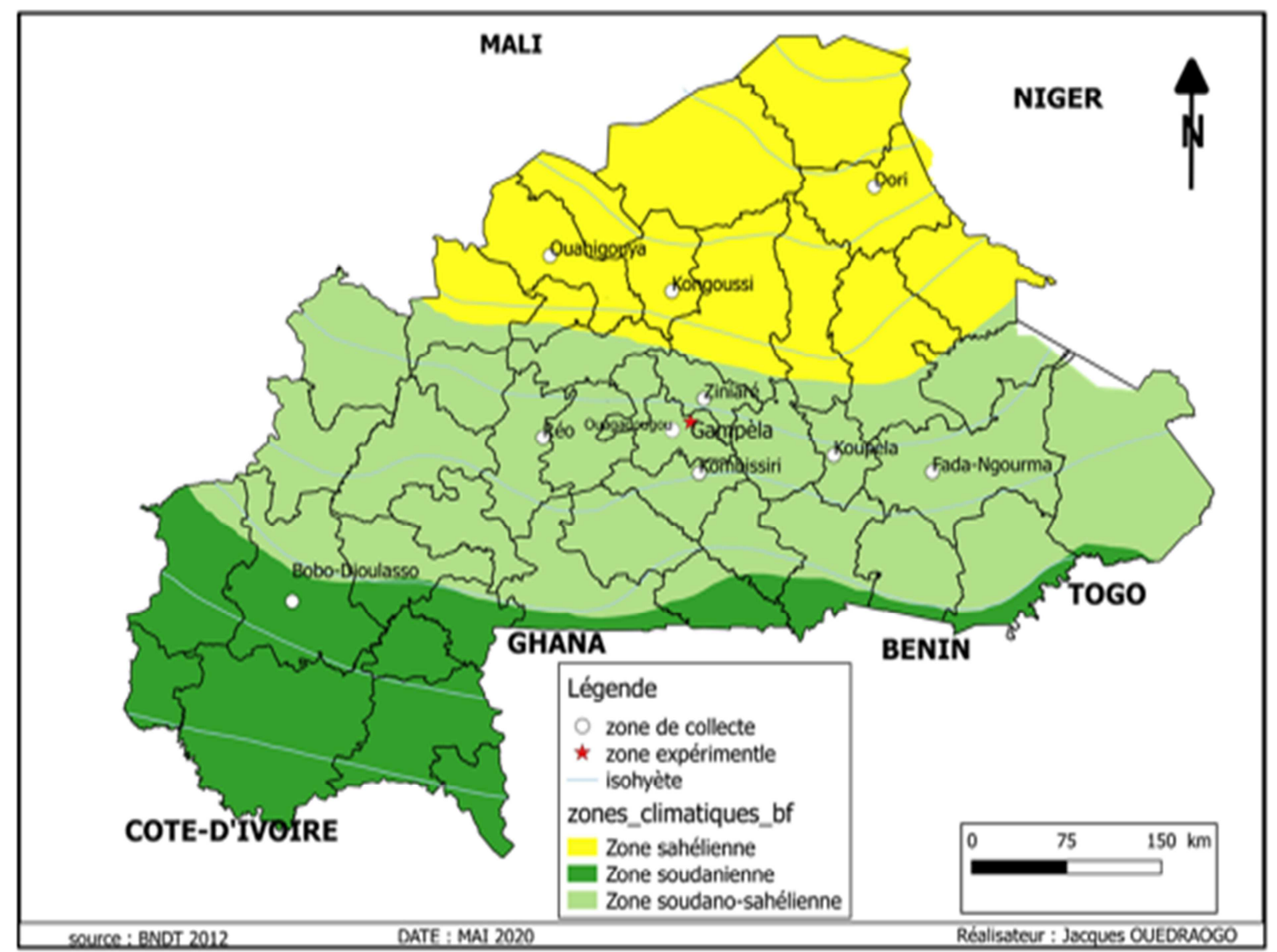

Figure 1. Survey and collection sites for Amaranthus ssp accessions. 


\subsection{Methods}

The measurements of morphological traits proposed by GrubbenG. J. H., Brenner D. M and Achigan-Dako focused respectively on twelve (12) quantitative and twelve (12) qualitative traits [11, 16-18].

The qualitative parameters observed were focused on the seedling color two weeks after sowing, the leaf color, the stem pigmentation, the leaf blade shape, the leaf margin shape, the stem color and the stem shape at the heading stage, the inflorescence density at the $50 \%$ flowering stage, the inflorescence color at the $50 \%$ flowering stage, the inflorescence shape, the seed color and root color.

With the exception of the number of days at $50 \%$ flowering and the number of days of inflorescence emergence which were assessed over the whole row, the other quantitative parameters were measured on three feet per row and per accession. These included the plant height, the stem height, the stem diameter, the petiole length, the blade width and length, the number of primary branches and number of primary branches bearing an inflorescence, the total weight of fresh leaves per plant and the length of inflorescence.

\subsection{Data Analysis}

Qualitative variables were subjected to descriptive analysis and proportion calculation. These variables were used as a key to identify the different species of amaranth [19]. For the quantitative variables, an analysis of variance (ANOVA) was performed using GenStat 4.10. Software to determine the traits that discriminate against accessions.

\section{Results}

\subsection{Morphological Variability of Accessions}

The analysis of the qualitative variables shows the existence of a great morphological diversity especially in terms of color and shape. In the color of the seedling, three variants were observed, namely green color $(85 \%)$, purple color $(12,5 \%)$ and violet color (02, 5\%) (Figure 2).

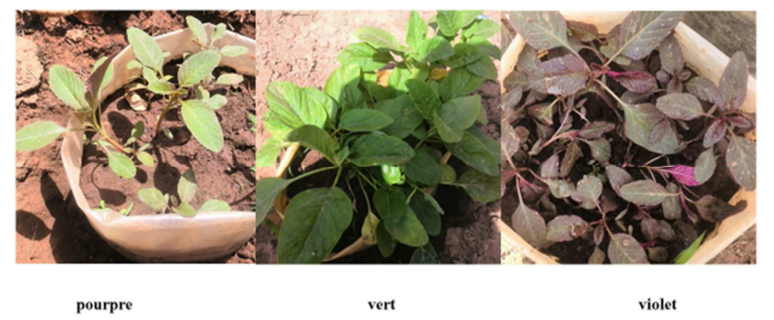

Figure 2. Color of seedlings at emergence.

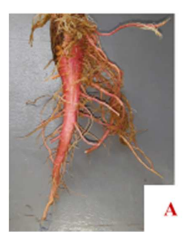

A: red roots,

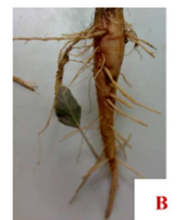

B: light pink roots

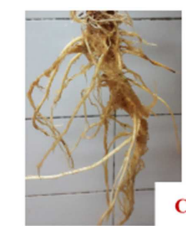

C: white roots.
Figure 3. Root colors in amaranth.
The root system is a shallow, pivoting type. Three color variations were observed, red (figure 3A), light pink (Figure 3B) and white (figure 3C). The majority of accessions had light pink roots $(56,25 \%)$. The other two types were red $(18$, $75 \%)$ and white $(25 \%)$.

The leaf color at the heading stage showed a wide variation from green to violet with a predominance of light green $(77,5 \%)$. The majority of leaves had a lanceolate leaf blade $(93,75 \%)$, others were oval or lanceolate oval.

The stem color identified five morphotypes namely green, purple, green-purple, green-purple and violet with a predominance of green morphotype (81,25\%).

At the inflorescence level, three color types were observed, namely green $(87,5 \%)$, purple $(10 \%)$ and violet $(2,5 \%)$ at the $50 \%$ flowering stage (figure 4 ). Depending on the shape of the inflorescence, accessions presented the bunch form $(93,75 \%)$, the Corymb form $(2,5 \%)$ or the branched spike form $(3,75 \%)$.

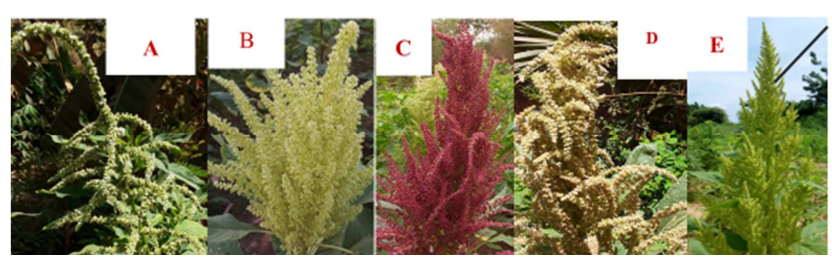

Figure 4. Colors and types of inflorescences in amaranth.

A: green inflorescence in branched spikes, B: green high-bush inflorescence, $\mathrm{C}$ : purple cluster inflorescence, D: purple cluster inflorescence, E: green cluster inflorescence.

At maturity, the accessions studied showed black (85\%), light-gold $(2,5 \%)$ and glossy dark-brown $(12,5 \%)$ seeds (figure 5).

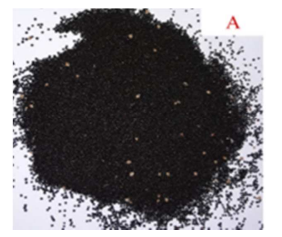

A: black grains

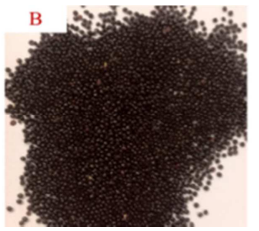

B: dark-brown grain

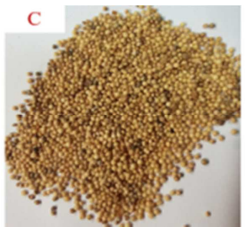

C: light-gold grains
Figure 5. Seed colors in amaranth.

\subsection{Identification of Cultivated Morphotypes and Species of the Genus Amaranthus}

The descriptors proposed by $[11,16,17]$ were used as a basis for identifying the 80 accessions cultivated in Burkina Faso. On the basis of qualitative characteristics, accessions were grouped into seven (07) morphotypes belonging to three species: A. cruentus, A. dibius and A. hypochondriacus.

\subsubsection{Species Amaranthus Cruentus}

Three morphotypes would belong to the species Amaranthus cruentus. They all have angular stems with lanceolate leaves and clustered inflorescences but differ in the color of the organs. They are: the green morphotype with green stem, green leaf blade and green inflorescences (figure $6 a$ ), the green-violet morphotype (intermediate between the first two morphotypes) with a green stem with purple stripes and leaves with green leaf blade but violet veins and 
inflorescence of the same color as the leaf blade veins (figure $6 \mathrm{~b}$ ) and the purple morphotype with violet stem, leaf (petiole

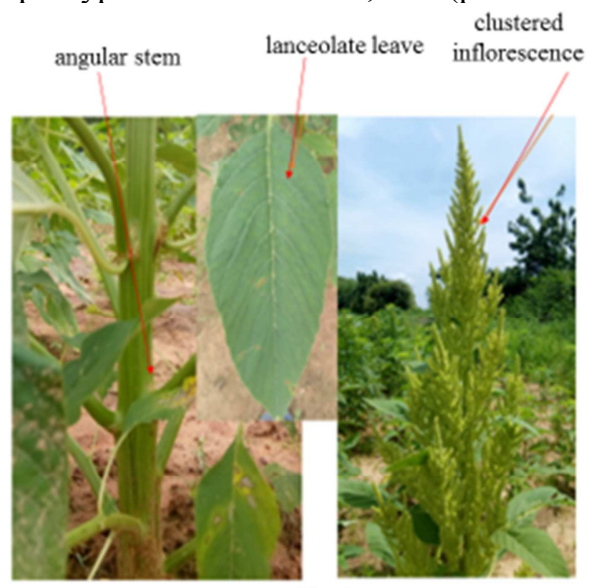

a: Green Morphotype and leaf veins) and violet inflorescence (figure 6c).

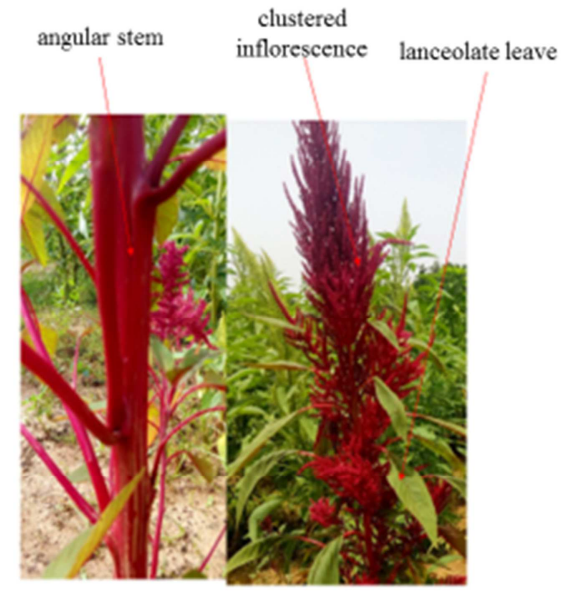

b: Green-violet Morphotype

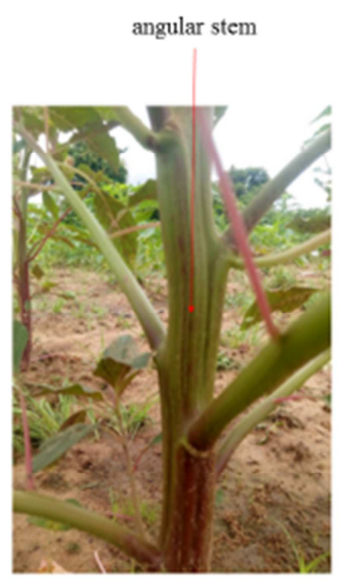

lanceolate leave

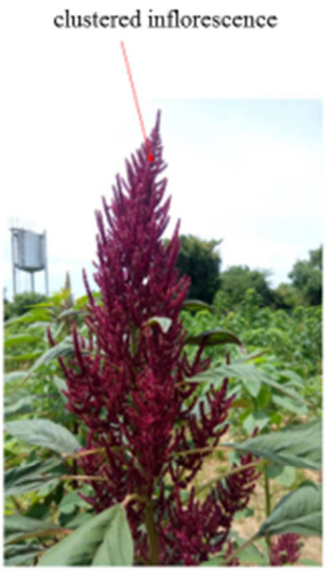

c: violet morphotype

Figure 6. Amaranthus cruentus.

\subsubsection{Species Amaranthus Hypochondriacus}

It is represented by three morphotypes with angular stems.

The purple morphotype with purple stems, lanceolate green-bladed leaves and clustered inflorescences (Figure 3 a).

The green-purple morphotype with a green stem with a purple base, lanceolate leaves and purple clustered inflorescences (Figure $3 \mathrm{~b}$ ).

The light green morphotype has a green stem with a purple base with leaves with a rounded green blade and light green inflorescences in corymb (Figure $3 \mathrm{c}$ ).

b: Purple Morphotype

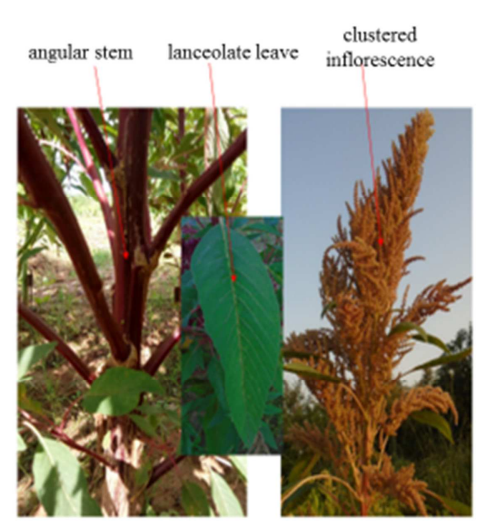

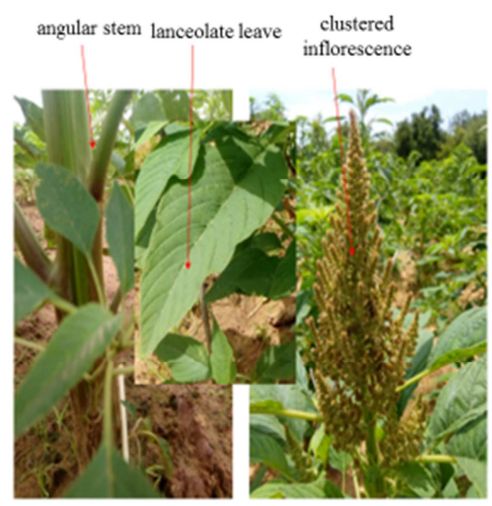

a: Green-purple Morphotype 


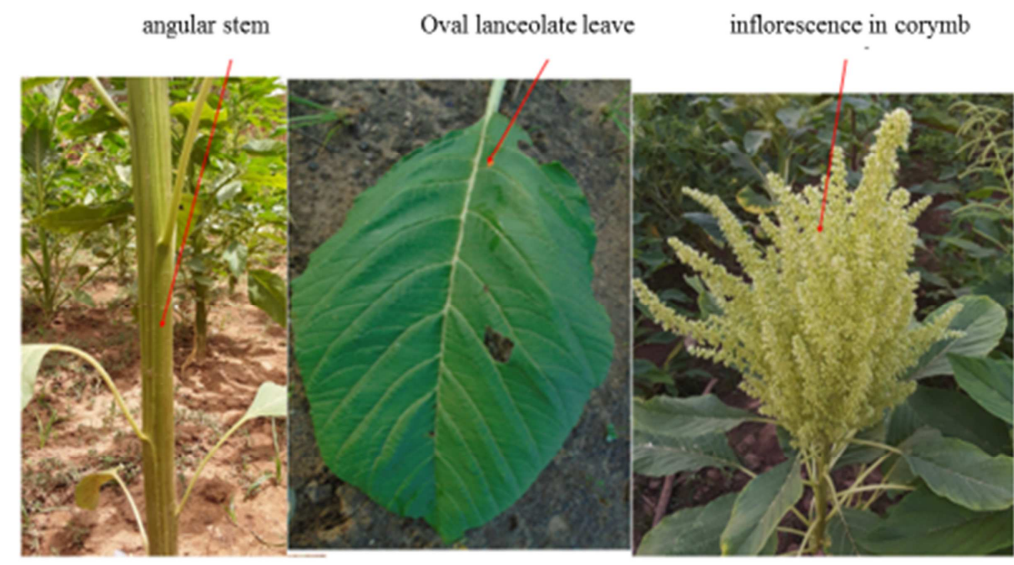

c: Light green morphotype

Figure 7. Amaranthus hypochondriacus.

\subsubsection{Species Amaranthus Dubius}

It is composed of a single morphotype: the dark green (Figure 8), with a dark green, angular stem with dark green, oval leaves and green, branched spike-shaped inflorescences.

Table 1 show the distribution of the 80 accessions according to species and morphotypes

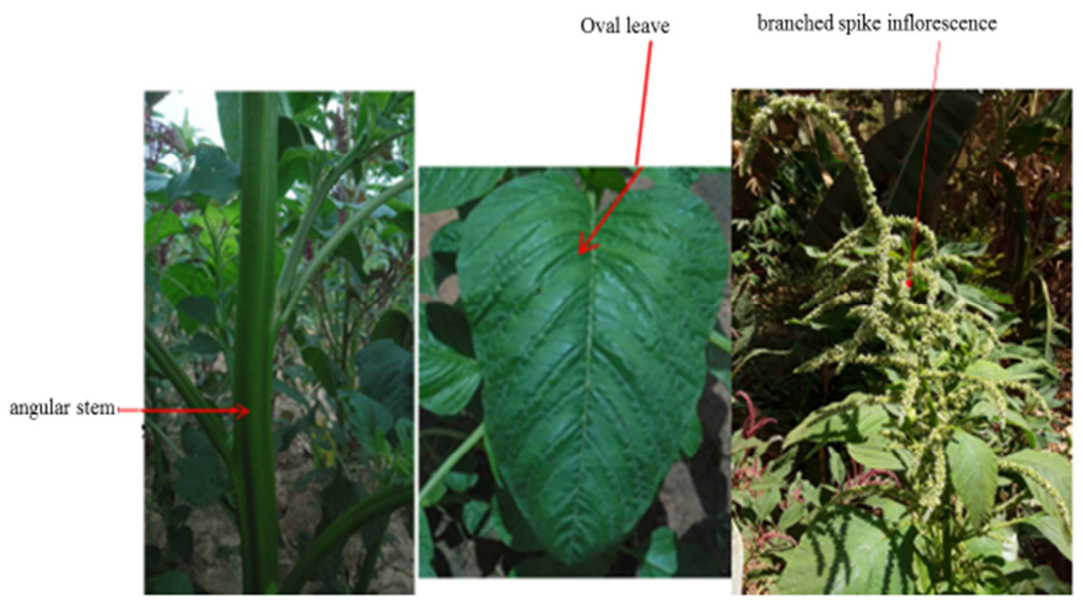

Figure 8. Dark Green Morphotype (Amaranthus dubius).

Table 1. Distribution of 80 accessions of Amaranthus spp. for qualitative characteristics.

\begin{tabular}{|c|c|c|c|c|c|c|c|}
\hline \multirow{2}{*}{ Morphotype } & \multirow{2}{*}{$\begin{array}{l}\text { Number } \\
80\end{array}$} & \multicolumn{5}{|c|}{ organs Characteristics } & \multirow[b]{2}{*}{ Species } \\
\hline & & root color & Stem shape & Leaf shapes & Inflorescence shape & Seeds Color & \\
\hline Green & 65 & Light pink Blanche & Angular & Lanceolate & clustered & Black & \\
\hline Violet & 01 & red & Angular & Lanceolate & clustered & Dark brown & Amaranthus Cruentus \\
\hline green-violet & 01 & red & Angular & Lanceolate & clustered & Dark brown & \\
\hline Light-green & 02 & red & Angular & Oval lanceolate & clustered & Or-Clair & \\
\hline Purple & 01 & red & Angular & Lanceolate & clustered & Dark brown & Amaranthus \\
\hline green-purple & 07 & red & Angular & Lanceolate & Corymb & Dark brown & \\
\hline Dark-green & 03 & red & Angular & Oval & Branched spikes & Black & Amaranthus Dubius \\
\hline
\end{tabular}

\subsection{Comparative Average Performance of the Identified Species of the Genus Amaranthus}

The results of the analyses of variance on the performance of the different morphotypes of the three species revealed a very significant difference at the $1 \%$ threshold for all quantitative traits studied. The green and purple morphotypes showed accessions with a long flowering cycle and reduced leaf blade width. The green morphotype has a 72.50 day flowering cycle, the purple morphotype has 73.56 days and the green-purple morphotype, intermediate between the two morphotypes, has 71.23 days. On the other hand, the light green and dark green morphotype presented plants with short flowering cycle and wide leaf blades with a very low number of primary branches. Among these morphotypes, the green of Amaranthus cruentus presented the best agronomic performances. These plants are large $(229.84 \mathrm{~cm})$ and robust with an average diameter of $41.23 \mathrm{~mm}$ with long blade leaves $(26.39 \mathrm{~cm})$. They present plants with many primary branches (45.64) and give a high leaf biomass. 
Table 2. Average performance of the species of the genus Amaranthus identified.

\begin{tabular}{|c|c|c|c|c|c|c|c|c|c|}
\hline \multirow{2}{*}{ Variable } & \multicolumn{3}{|c|}{ Amaranthus cruentus } & \multicolumn{2}{|c|}{ Amaranthus Hypochondriacus } & \multicolumn{2}{|c|}{ Amaranthus dubius } & \multirow{2}{*}{$\mathbf{R}^{2}$} & \multirow{2}{*}{$\operatorname{Pr}>\mathbf{F}$} \\
\hline & green & violet & green-violet & green-purple & purple & light-green & dark-green & & \\
\hline Number of days of inflorescence & 63,16 & 57,17 & 49,89 & 61,57 & 62,78 & 47,97 & 49,22 & 0,25 & $<0,0001$ \\
\hline Number of days at $50 \%$ flowering & 72,50 & 67,11 & 59,44 & 71,23 & 73,56 & 56,97 & 57,62 & 0,24 & $<0,0001$ \\
\hline Plant height & 229,84 & 166,53 & 164,78 & 193,75 & 186,00 & 175,56 & 184,75 & 0,16 & $<0,0001$ \\
\hline Stem height & 283,57 & 161,67 & 193,00 & 200,82 & 210,00 & 142,50 & 135,37 & 0,22 & $<0,0001$ \\
\hline Stem diameter & 173,58 & 116,97 & 116,00 & 138,78 & 141,89 & 135,75 & 130,22 & 0,17 & $<0,0001$ \\
\hline Number of primary branches & 41,23 & 28,39 & 36,44 & 35,82 & 32,50 & 31,33 & 33,47 & 0,10 & 0,000 \\
\hline Petiole length & 41,67 & 26,33 & 28,78 & 33,05 & 34,83 & 14,00 & 16,70 & 0,31 & $<0,0001$ \\
\hline Blade width & 16,05 & 12,42 & 17,30 & 12,67 & 16,09 & 16,91 & 15,18 & 0,10 & 0,000 \\
\hline Blade length & 26,39 & 20,63 & 23,71 & 22,36 & 22,62 & 25,50 & 17,65 & 0,17 & $<0,0001$ \\
\hline Length of inflorescence & 11,41 & 8,95 & 9,80 & 8,26 & 8,91 & 14,09 & 13,17 & 0,16 & $<0,0001$ \\
\hline Weight of fresh leaves per plant & 57,10 & 49,94 & 48,78 & 55,67 & 44,11 & 46,75 & 57,73 & 0,07 & 0,015 \\
\hline
\end{tabular}

\section{Discussion}

Amaranths are plants most often found in the form of weeds. Few are known, therefore ignored. In fact, the number of species is still provisional due to a poor application of names and synonyms applied to misidentified names [20]. However, in recent years, research shows that they are among the plants that show promise for the future. They are not only popular in Africa, but are widely consumed and cultivated throughout the world [21]. In Burkina Faso, of the six species identified (Amaranthus. dubius, Amaranthus graecizans, Amaranthus cruentus, Amaranthus hypochondriacus, Amaranthus viridis Amaranthus spinosus) [22, 23], only three species are cultivated according to this study. These are Amaranthus cruentus, Amaranthus hypochondriacus and Amaranthus dubius, considered the most popular species in Africa and widely consumed. The absence of the other three species (Amaranthus viridis, Amaranthus spinosus and Amaranthus graecizans) in the present collection is justified by the fact that many species of larder beetles are still considered to be spontaneous species. In general, cultivated species can be classified into two main groups, those cultivated for their edible leaves and those cultivated for their seeds [20]. The three species cultivated in Burkina Faso for their leaves are divided into the two groups. Among the grain amaranths, Amaranthus hypochondriacus $\mathrm{L}$. is the most robust and productive type. It shows a diversity of habits. The species is suitable for tropical areas and dry conditions. It has the greatest potential to be used as a food ingredient because of the excellent quality of these seeds. Amaranthus dubius L. is cultivated only for its leaves. As for the species Amaranthus cruentus L. It is used both as a source of pseudo-cereal and leaf vegetable. Also according to Das Saubhik, Amaranthus cruentus consists of two types: the white grain type used as pseudo-cereal and the brown or black grain type used as vegetable [20]. Thus, of the seven morphotypes defined by their branching pattern, height, size and shape of the inflorescence, cycle, grain color and other morphological characteristics [24-26], the green morphotype with black grains of the species Amaranthus cruentus is the most cultivated and the most consumed in
Burkina Faso as well as in other West African countries such as Benin, Ivory Coast, Togo, Nigeria and Senegal. According to Diouf M., Assogba Komlan F. and Somtore H, it is the most produced and appreciated by women in all urban, peri-urban and rural areas of tropical Africa $[9,27$, 28]. In general, the color green seems to be a selection trait for producers and preferred by consumers, especially women, in the production of leafy vegetables in West Africa $[2,29,30]$. Indeed, consumer preference and socioeconomic scenario determine the particular characteristics that can be found in a growing medium. The better agronomic performance of green-leaved Amaranthus cruentus gives it a particular interest in a selection and improvement program for leaf production. On the other hand, the light green morphotype of Amaranthus hypochondriacus could be cultivated for its seeds as in other countries: Madagascar, Ethiopia, and Nepal Mongolia $[31,32]$.These two morphotypes have a great adaptability to the agro-pedological conditions of the tropical zones thus making it possible to develop new varieties wished by the modern breeder. They are very rich in micronutrients [31, 33] and could be promoted in the fight against chronic malnutrition in children.

\section{Conclusion}

The amaranths cultivated in Burkina Faso present a great morphological variability. This characterization allowed us to identify seven morphotypes divided into three species. All the quantitative parameters studied significantly discriminated the seven morphotypes of the three species. The green morphotypes with the best agronomic performance, green-violet and violet all belong to the species Amaranthus cruentus. The species Amaranthus hypochondriacus consists of three morphotypes: green-purple, purple and green-light. We note at the end, the dark green morphotype of the species Amaranthus dubius.

It would also be interesting to valorize the plant especially the light-green morphotype of the species Amaranthus hypochondriacus through the consumption of the seeds which are very rich in micronutrients and energetic food.

A molecular study will allow further identification of the amaranth species in Burkina Faso. 


\section{References}

[1] Andini R., S. Yoshida, and R. Ohsawa, (2013 May). Variation in protein content and amino acids in the leaves of grain, vegetable and weedy types of Amaranths. Agronomy. 3: 391403. doi:10.3390/agronomy3020391

[2] Dinssa F. F., Hanson P., Dubois T.; Tenkouano A., Stoilova T., Hughes J. A., Keatinge J. D. H., 2016. AVRDC - The World Vegetable Center's women-oriented improvement and development strategy for traditional African vegetables in subSaharan Africa. Europ.J.Hortic.Sci. 81(2): 91-105. Doi: 10.17660/eJHS.2016/81.2.3

[3] R. S. Katiyar, Shukla S., V. Rai., 2000. Varietal performance of grain amaranths (A. hypochondriacus) on sodic soil. Proc. Natl. Acad. Sci. India, 70, pp. 185-187.

[4] Shukla S., Singh S. P., 2000. Studies on genetic parameters in vegetable amaranth. Journal of Genetics and Breeding, 54: 133-135.

[5] Drinic Mladenovic Snezana, Kostadinovic Marija, Ristic Danijela, Simic Milena and Stefanovic Lidija, 2012. Assessment of genetic relatedness of the two Amaranthus retroflexus populations by protein and random amplified polymorphic DNA (RAPD) markers. African Journal of Biotechnology. 11(29): 7331-7337. doi:10.5897/AJB11.1254.

[6] Caburet A., Daly P. Bon H., Huat J., Langlais C., Lyannaz J. P., et Ryckewaert P., 2002. Les légumes In: MÉMENTO de l'Agronome. CIRAD-GRET/ MFAE, Ed ISBN: 2-86844-1297, p. 1023-1050.

[7] Hama-Ba F., Parkouda C., Kamga R., Tenkouano A., Diawara B., 2017. Disponibilité, modes et fréquence de consommation des légumes traditionnels africains dans quatre localités du Burkina Faso a diverses activités de maraichage: Ouagadougou, Koubri, Loumbila, Kongoussi. Afr. J. Food Agric. Nutr. Dev. 17(1). 11552-11570

[8] Annuaire Des Statistiques Agricoles, 2018. Aménagements hydro-agricoles et irrigations. Ministère de l'Agriculture et des Aménagement Hydro-Agricoles/Enquête Permanente Agricole 2009-2018, pp. 41-42.

[9] Somtore H., Sawadogo B., Bationo-Kando P., Kiebre M., Ouedraogo J. and Kiebre Z. 2019. Ethnobotanical Investigation of Amaranth (Amaranthus spp) Cultivated in Burkina. International Journal of Applied Agricultural Sciences. 5(2): $50-55 . \quad$ https://doi: 10.11648/j.ijaas.20190502.14

[10] Berger A., Monnard I., Dionisi F., Gumy D., Hayes K. C., Lambelet P. 2003. Cholesterol-lowering properties of amaranth flakes, crude and refined oils in hamsters. Food Chem., 81:119-124. https://doi.org/10.1016/S0308-8146 (02) $00387-4$

[11] Achigan-Dako, E. G., Sogbohossou, O. E. D., Maundu, P., 2014. Current knowledge on Amaranthus spp.: research avenues for improved nutritional value and yield in leafy amaranths in sub-Saharan Africa. Euphytica 197, 303-317. http://dx.doi.org/10. 1007/s10681-014-1081-9.

[12] FAO, 2017. The world food and agriculture situation: the role of women in agriculture, $174 p$.

[13] Gudu S. and Gupta V. K., 1988. Male-sterility in the grain amaranth (Amaranthus hypochondriacus ex-Nepal) variety Jumla. Euphytica, 37: 23-26.

[14] Vojtech Lanta, Pavel Havranck, Vladan, 2003. Morphometry analysis and seed germination ofAmaranthus Cruentus, A. retroflexus and their hybrid (A. Z turicensis). PANT SOIL ENVIRON. 49, 8: 364-369.

[15] Mayuri J. Gelotar, S. D. Soanki and N. N. Prajapati, 2019. Evaluation of outcrossing rate in different species of grain amaranth. The Pharma Innovation Journal. 8(12): 65-67.

[16] Grubben G. J. H., 1975. La culture de l'amarante, légumefeuilles tropical: Avec référence spéciale au sud-Dahomey. Mededelingen Landbouwhogeschool, Wageningen.

[17] Grubben G. J. H., Denton O. A., 2004. Plant Resources of Tropical Africa 2: Vegetables. PROTA, Wageningen, Netherlands, 668 p.

[18] Brenner D. M., 2002. Amaranth Descriptor. Descriptor Site(s): NC7; USDA: Iowa City, IA, USA. pp. 1-13. Available online: $\mathrm{http}: / /$ www.ars-grin.gov/npgs/descriptors/amaranth (accessed on 14 March 2013).

[19] Xiao S. G., Liu, Y. Song and G. Yang, 2000. Classification of vegetable amaranth variety resources. Journal of Hunan Agricultural University. 26 (4): 274-277.

[20] Das Saubhik., 2016. Amaranthus: A Promising Crop of Future. doi: 10.1007/978-981-10-1469-7_3

[21] National Research Council, 2006. Lost Crops of Africa: Volume II: Vegetables. Washington. DC: The National Academies Press. pp. 35-51. https://doi.org/10.17226/11763.

[22] Ouédraogo I., Hilou A., Sombié P. A. E. D., Compaore M., Millogo J. and Nacoulma O. G., 2011. Nutraceutical Assessment of Four Amaranthus Species from Burkina Faso. Current Research J. Biol. Sci. 3(5), 8p 451-458.

[23] Somtore H., 2017 Etude de la Diversité Agromorphologique d'Accessions d'Amarante (Amaranthus spp) du Centre-Ouest et de l'Ouest du Burkina Faso. Master Professionnel en Sélection et Valorisation des Ressources Phyto-Génétiques, Univ. Ouaga.: $49 p$.

[24] Kauffman C. S. 1992. Realizing the potential of grain amaranth. Food Rev. Int., 8:5-21.

[25] Espitia-Rangel E. 1994. Breeding Of grain amaranth. In: Peredes-lopezo (ed.): Amaranth biology, chemistry and technology CRC Press, Boca Raton.

[26] Brenner D. M.; Baltensperger, D. D.; Kulakow, P. A.; Lehmann, J. W.; Myers, R. L.; Slabbert, M. M.; Sleugh, B. B, 2000. Genetic resources and breeding of Amaranthus. Plant Breed. Rev., 19, 227-285.

[27] Diouf M., Mbengue N. B. and Kanté À., 2007. Caractérisation des accessions de 4 espèces de légumes feuilles traditionnelles (Hibiscus sabdariffa L. Vignaunguiculata (L.) WALP, Amaranthus L. spp et Moringa oleifera LAM) au Sénégal. African Journal of food agriculture and nutrition. Vol 7(3) 16 pages. www.kopkenya.org.

[28] Assogba Komlan F., Sikirou R., Yo T., Adanguidi J. \& A. C. G. Mensah, 2016. La culture de l'Amarante (Fotêtê en fongbé) au Bénin. Fiche technique FAO. Dépôt légal $\mathrm{N}^{\circ} 8552 \mathrm{du}$ 19/02/16. Bibliothèque Nationale, 1er trimestre. ISBN: 97899919-2-126-6. 16p. 
[29] Fondio L., Mahyao A., Agbo A. E., Gbesso M. F., 2012.. Bien cultiver l'amarante, la célosie, la corète potagère et la morelle noire en Côte d'Ivoire. Centre National de Recherche Agronomique, $4 \mathrm{p}$.

[30] Kiebre Zakaria, 2016. Diversité génétique du Caya blanc (Cleome gynandra L.) du Burkina Faso, Thèse doct. Univ. Ouaga, Burkina Faso. 126 pages.

[31] R. H. Mandanirina, 2006. Valorisation des graines d'amarante (Amaranthus hybridus hypochondriacus) en alimentation infantile. Mémoire pour l'obtention du diplôme d'études approfondies de biochimie, Université d'Antananarivo Faculté des Sciences, Madagascar. 66p.
[32] Dinssa F. F., Yang R. C, Ledesma D. R., Mbwambo O., Hanson P., 2018. Effect of leaf harvest on grain yield and nutrient content of diverse amaranth entries. Scientia $\begin{array}{lll}\text { Horticulturae. } & \text { 236: } & \text { 146-157. Doi: }\end{array}$ 10.1016/j.scienta.2018.03.028

[33] Nana Constance P., Brouwer Inge D., Traoré Alfred S. 2003. Consommation alimentaire des enfants de 6 à 36 mois en milieu rural en fonction de la disponibilité des aliments riches en vitamine A. 2ème Atelier international: voies alimentaires d'amélioration des situations nutritionnelles. Ouagadougou, 23-28 / 11 / 2003. 